Jurnal Keperawatan Silampari

Volume 4, Nomor 2, Juni 2021

e-ISSN: 2581-1975

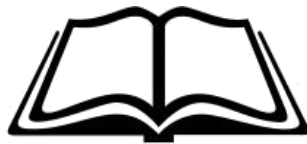

p-ISSN: 2597-7482

DOI: https://doi.org/10.31539/jks.v4i2.1937

DMEKpE

\title{
PEMBERIAN NASI BERAS MERAH (ORIZA NIVARA) DAN NASI BERAS HITAM (ORIZA SATIVA L. INDICA) TERHADAP PERUBAHAN KADAR GLUKOSA PADA PENDERITA DIABETES MELLITUS
}

\author{
Laode Ardiansyah ${ }^{1}$, Nawawi ${ }^{2}$ \\ Sekolah Tinggi Ilmu Kesehatan Mandala Waluya Kendari ${ }^{1,2}$ \\ Laodeardiansyah22@gmail.com ${ }^{1}$
}

\begin{abstract}
ABSTRAK
Penelitian ini bertujuan untuk mengetahui pengaruh pemberian nasi beras merah (Oriza Nivara) dan nasi beras hitam (Oriza Sativa L. Indica) terhadap perubahan kadar glukosa darah pada penderita diabetes mellitus di Kota Kendari. Metode penelitian ini dilakukan dengan desain quasi eksperimen dengan uji pre-post test design. Hasil penelitian pada pemeriksaan kadar glukosa darah sebelum dan sesudah pemberian nasi beras merah (Oriza Nivara) dan nasi beras hitam (Oriza Sativa L. Indica) dalam waktu 1 minggu diperoleh pvalue $=0,000$ dari $\mathrm{p}$-value $<0,05$, sedangkan pada perbandingan antara nasi beras merah (Oriza Nivara) dan nasi beras hitam (Oriza Sativa L. Indica) terhadap perubahan glukosa darah pada penderita diabetes mellitus di Kota Kendari diperoleh p-value $=0,19$. Simpulan, ada pengaruh pemberian nasi beras merah (Oriza Nivara) dan nasi beras hitam (Oriza Sativa L. Indica) terhadap perubahan glukosa darah pada penderita diabetes mellitus di Kota Kendari.
\end{abstract}

Kata Kunci: Diabetes Mellitus, Kadar Glukosa Darah, Nasi Beras Hitam, Nasi Beras Merah

\section{ABSTRACT}

This study aims to determine the effect of giving brown rice (Oryza Nivara) and black rice (Oryza Sativa L. Indica) to changes in blood glucose levels in people with diabetes mellitus in Kendari City. This research method was carried out with a quasi-experimental design with a pre-post test design test. The results of the study on checking blood glucose levels before and after giving brown rice (Oryza Nivara) and black rice (Oryza Sativa L. Indica) within one week obtained P-Value $=0.000$ from $P$-Value $<0.05$, while in comparison between brown rice (Oryza Nivara) and black rice (Oryza Sativa L. Indica) on changes in blood glucose in people with diabetes mellitus in Kendari City obtained P-Value $=0.19$. In conclusion, there is an effect of giving red rice (Oryza Nivara) and black rice (Oryza Sativa L. Indica) on changes in blood glucose in people with diabetes mellitus in Kendari City.

Keywords: Diabetes Mellitus, Blood Glucose Level, Black Rice, Brown Rice 


\section{PENDAHULUAN}

Kesehatan menjadi prioritas masalah yang dihadapi oleh pemerintah dan masyarakat Di Indonesia. Salah satu jenis penyakit yang dialami masyarakat adalah diabetes mellitus. DM merupakan suatu penyakit yang disebabkan tubuh tidak mampu menghasilkan insulin (hormon yang memproduksi glukosa darah) atau pasokan insulin yang dihasilkan tidak mencukupi. Hal ini dapat menyebabkan terjadinya peningkatan glukosa dalam darah (Kemenkes RI, 2019).

Data terbaru dari International Diabetes Federation tahun 2017 menunjukkan bahwa Indonesia saat ini menduduki peringkat ke-6 dunia dengan jumlah penderita diabetes terbesar, yaitu sebanyak 10,3 juta jiwa (Depkes, 2018; Sartika et al., 2020; Setyawati et al., 2020). Hasil Riset Kesehatan Dasar, Riskesdas tahun 2018 menunjukkan bahwa prevalensi penderita diabetes naik mejadi 8,5 persen, dari 6,9 persen (Riskesdas, 2018).

Diabetes mellitus sangat erat kaitannya dengan kadar glukosa darah, sehingga diperlukan pemeriksaan glukosa darah sewaktu. Peran pengaturan pola makan pada penderita diabetes dalam pengendalian kadar gula darah sehingga kadar gula darah tetap terkontrol (Susanti \& Bistara, 2018). Pengendalian kadar glukosa darah pada penderita diabetes mellitus berhubungan dengan asupan makanan berlebih yang mengakibatkan peningkatan kadar gula darah (Edy \& Adinugraha, 2017). Peningkatan glukosa darah (hiperglikemia) dapat menyebabkan rusaknya sel-sel $\beta$ pangkreas penghasil insulin. Radikal bebas seperti supraoksida, hydrogen peroksida, nitrat oksida dan hidroksil yang merusak selsel $\beta$ pangkreas sehingga jumlah insulin yang dihasilkan oleh tubuh akan berkurang. Ini menyebabkan glukosa tidak dapat masuk ke sel dan menumpuk di dalam darah sehingga menimbulkan kondisi hiperglikemia. Pada kasus ini antioksidan dibutuhkan melawan radikal bebas. Antioksidan untuk mengatasi penurunan glukosa darah pada penderita DM adalah nasi beras merah (Oriza Nivara) dan nasi beras hitam (Oriza Sativa L. Indica).

Beras merah (Oriza Nivara) adalah bagian dari tanaman herbal yang mengandung karbohidrat, lemak, protein, serat dan mineral juga mengandung senyawa flavonoid yang memiliki kemampuan sebagai antidiabetes yang menurunkan glukosa darah dengan meningkatkan sekresi insulin dan mencegah resistansi insulin (Firdausya \& Amalia, 2020). Pada nasi beras hitam (Oriza Sativa L. Indica) mengandung senyawa aktif sianidin-3glukosida yang dapat memperbaiki keadaan hiperglikemia dan sensitivitas insulin serta memiliki efek sinergis menghambat enzim $\alpha$-glukosidase dan $\alpha$-amilase.

Penelitian tentang beras merah dan beras hitam terhadap kadar glukosa darah sudah pernah dilakukan, akan tetapi hanya fokus pada salah satunya saja. Namun dalam penelitian ini, berfokus pada pemberian nasi beras merah (Oriza Nivara) dan nasi beras hitam (ORIZA Sativa L. Indica) terhadap perubahan kadar glukosa darah pada penderita diabetes mellitus.

\section{METODE PENELITIAN}

Jenis penelitian yang digunakan adalah quasi eksperimen design dengan desain uji pre-post test design. Pre-post test design merupakan penelitian yang dilakukan dengan cara memberikan Pretest terlebih dahulu sebelum diberikan intervensi, setelah itu diberikan intervensi, kemudian dilakukan posttest. 
Penelitian ini dilaksanakan di Kota Kendari dengan populasi penderita penyakit DM yang berada di Kota Kendari berdasarkan data Dinas Kesehatan Kota Kendari pada tahun 2018 berjumlah 190 orang. Untuk menentukan jumlah sampel penelitian ini adalah dengan menggunakan rumus solvin sehingga diperoleh jumlah sampel ada 66 penderita diabetes mellitus.

Hasil dari penghitungan menggunakan rumus tersebut adalah jumlah sampel dibagi menjadi 2 kelompok yaitu 33 sampel akan diberikan nasi beras merah (Oriza Nivara) dan 33 sampel akan diberikan nasi berah hitam (Oriza Sativa L. INDICA). Perlakukan diberikan selama 1 minggu dengan pengukuran glukosa darah sebelum diberikan dan sesudah diberikan intervensi pada penderita DM, dengan keterangan tes GDS pada plasma vena $\leq$ $100 \mathrm{mg} / \mathrm{dL}$ berarti GDS normal atau menurun, jika $\geq 200 \mathrm{mg} / \mathrm{dL}$ berarti GDS tidak normal atau tidak terjadi penurunan sedangkan pada pengukuran GDS pada kapiler $\leq 90 \mathrm{mg} / \mathrm{dL}$ berarti GDS normal atau menurun, jika $\geq 200 \mathrm{mg} / \mathrm{dL}$ berarti GDS tidak normal atau tidak terjadi penurunan (Bagian Patologi Klinik Universitas Hasanuddin, 2018).

\section{HASIL PENELITIAN}

\section{Distribusi Responden Berdasarkan Kelompok Umur}

Tabel. 1

Distribusi Responden

Berdasarkan Kelompok Umur

\begin{tabular}{llcc}
\hline No & Kelompok Umur (tahun) & $\mathrm{n}$ & $\%$ \\
\hline 1. & $40-49$ & 12 & 18,18 \\
2. & $50-59$ & 18 & 27,27 \\
3. & $60-69$ & 21 & 31,82 \\
4. & $\geq 70$ & 15 & 22,73 \\
\hline \multicolumn{2}{l}{ Jumlah } & 66 & 100 \\
\hline
\end{tabular}

Berdasarkan tabel 1 menunjukkan bahwa kelompok umur paling banyak yakni pada usia 60-69 tahun yaitu sebanyak $21(31,82 \%)$.

\section{Distribusi Responden Berdasarkan Jenis Kelamin}

Tabel. 2

Distribusi Responden

Berdasarkan Jenis Kelamin

\begin{tabular}{llcc}
\hline No & Jenis Kelamin & $\mathrm{n}$ & $\%$ \\
\hline 1. & Laki -laki & 27 & 40,91 \\
2. & Perempuan & 39 & 59,09 \\
\hline Jumlah & 66 & 100 \\
\hline
\end{tabular}

Berdasarkan tabel 2 menunjukkan bahwa jenis kelamin sebagian besar responden adalah perempuan berjumlah 39 orang $(59,09 \%)$. 


\section{Pengukuran Kadar Glukosa Darah Sebelum dan Sesudah Pemberian Nasi Beras Merah (Oriza Nivara)}

Tabel. 3

Pengukuran Kadar Glukosa Darah Sebelum dan Sesudah

Pemberian Beras Merah (Oriza Nivara)

\begin{tabular}{|c|c|c|c|c|}
\hline \multirow[b]{2}{*}{ No } & \multicolumn{2}{|c|}{ Perubahan Glukosa Darah } & \multirow[b]{2}{*}{ Nilai Selisih } & \multirow[b]{2}{*}{$\begin{array}{l}\text { Keterangan Normal } \\
\quad \leq 200 \mathrm{mg} / \mathrm{dL}\end{array}$} \\
\hline & $\begin{array}{l}\text { Pre Test } \\
(\mathrm{mg} / \mathrm{dL})\end{array}$ & $\begin{array}{c}\text { Post Test (1 } \\
\text { Minggu) (mg/dl) }\end{array}$ & & \\
\hline 1 & 485 & 527 & -42 & Tidak normal \\
\hline 2 & 561 & 328 & 233 & Tidak normal \\
\hline 3 & 350 & 268 & 82 & Tidak normal \\
\hline 4 & 220 & 109 & 111 & Normal \\
\hline 5 & 201 & 319 & -118 & Tidak normal \\
\hline 6 & 215 & 137 & 78 & Normal \\
\hline 7 & 228 & 149 & 79 & Normal \\
\hline 8 & 298 & 334 & -36 & Tidak normal \\
\hline 9 & 500 & 328 & 172 & Tidak normal \\
\hline 10 & 450 & 220 & 230 & Tidak normal \\
\hline 11 & 550 & 245 & 305 & Tidak normal \\
\hline 12 & 448 & 248 & 200 & Tidak normal \\
\hline 13 & 240 & 185 & 55 & Normal \\
\hline 14 & 550 & 245 & 305 & Tidak normal \\
\hline 15 & 374 & 184 & 190 & Normal \\
\hline 16 & 450 & 129 & 321 & Normal \\
\hline 17 & 260 & 138 & 122 & Normal \\
\hline 18 & 285 & 195 & 90 & Normal \\
\hline 19 & 276 & 152 & 124 & Normal \\
\hline 20 & 347 & 198 & 149 & Normal \\
\hline 21 & 545 & 238 & 307 & Tidak normal \\
\hline 22 & 336 & 185 & 151 & Normal \\
\hline 23 & 274 & 128 & 146 & Normal \\
\hline 24 & 380 & 192 & 188 & Normal \\
\hline 25 & 420 & 200 & 220 & Normal \\
\hline 26 & 229 & 138 & 91 & Normal \\
\hline 27 & 580 & 258 & 322 & Tidak normal \\
\hline 28 & 420 & 209 & 211 & Tidak normal \\
\hline 29 & 480 & 198 & 282 & Normal \\
\hline 30 & 385 & 182 & 203 & Normal \\
\hline 31 & 450 & 216 & 234 & Tidak normal \\
\hline 32 & 480 & 200 & 280 & Normal \\
\hline 33 & 300 & 165 & 135 & Normal \\
\hline Jumlah & 12567 & 7147 & 5420 & \\
\hline
\end{tabular}

Berdasarkan tabel 3 menunjukkan bahwa hasil pengukuran responden penderita diabetes mellitus di Kota Kendari sebelum dan sesudah pemberian nasi beras merah (Oriza Nivara) selama satu minggu dengan frekuensi 3 kali sehari dengan porsi disesuaikan kebutuhan kalorinya. Penderita diabetes mellitus yang mengalami perubahan kadar glukosa 
darah normal berjumlah 19 responden, dan yang tidak mengalami perubahan normal tetapi masuk setelah diberikan intervensi beras merah (Oriza Nivara) adalah berjumlah 14 orang.

\section{Pengukuran Kadar Glukosa Darah Sebelum dan Sesudah Pemberian Nasi Beras Hitam (Oriza Sativa L. Indica)}

Tabel. 4

Pengukuran Kadar Glukosa Darah Sebelum dan Sesudah Pemberian Nasi Beras Hitam (Oriza Sativa L. Indica)

\begin{tabular}{|c|c|c|c|c|}
\hline \multirow[b]{2}{*}{ No } & \multicolumn{2}{|c|}{ Perubahan Glukosa Darah } & \multirow[b]{2}{*}{ Nilai Selisih } & \multirow{2}{*}{$\begin{array}{c}\text { Keterangan } \\
\text { Normal } \\
\leq 200 \mathrm{mg} / \mathrm{dL}\end{array}$} \\
\hline & $\begin{array}{l}\text { Pre Test } \\
(\mathrm{mg} / \mathrm{dL})\end{array}$ & $\begin{array}{c}\text { Post Test }(1 \\
\text { Minggu }(\mathrm{mg} / \mathrm{dl})\end{array}$ & & \\
\hline 1 & 350 & 185 & 165 & Normal \\
\hline 2 & 561 & 328 & 233 & Tidak normal \\
\hline 3 & 290 & 177 & 113 & Normal \\
\hline 4 & 250 & 156 & 94 & Normal \\
\hline 5 & 409 & 353 & 56 & Tidak normal \\
\hline 6 & 220 & 156 & 64 & Normal \\
\hline 7 & 328 & 105 & 223 & Normal \\
\hline 8 & 460 & 187 & 273 & Normal \\
\hline 9 & 380 & 194 & 186 & Normal \\
\hline 10 & 416 & 154 & 262 & Normal \\
\hline 11 & 298 & 127 & 171 & Normal \\
\hline 12 & 320 & 189 & 131 & Normal \\
\hline 13 & 580 & 198 & 382 & Normal \\
\hline 14 & 390 & 200 & 190 & Normal \\
\hline 15 & 345 & 195 & 150 & Normal \\
\hline 16 & 292 & 126 & 166 & Normal \\
\hline 17 & 250 & 115 & 135 & Normal \\
\hline 18 & 534 & 216 & 318 & Tidak normal \\
\hline 19 & 319 & 125 & 194 & Normal \\
\hline 20 & 420 & 199 & 221 & Normal \\
\hline 21 & 386 & 200 & 186 & Normal \\
\hline 22 & 382 & 175 & 207 & Normal \\
\hline 23 & 258 & 112 & 146 & Normal \\
\hline 24 & 290 & 137 & 153 & Normal \\
\hline 25 & 520 & 200 & 320 & Normal \\
\hline 26 & 235 & 147 & 88 & Normal \\
\hline 27 & 298 & 182 & 116 & Normal \\
\hline 28 & 320 & 165 & 155 & Normal \\
\hline 29 & 350 & 196 & 154 & Normal \\
\hline 30 & 475 & 168 & 307 & Normal \\
\hline 31 & 585 & 200 & 385 & Normal \\
\hline 32 & 359 & 182 & 177 & Normal \\
\hline 33 & 500 & 168 & 332 & Normal \\
\hline Jumlah & 12370 & 5917 & 6453 & \\
\hline
\end{tabular}

Berdasarkan tabel 4 menunjukkan bahwa hasil pengukuran responden penderita diabetes mellitus di Kota Kendari sebelum dan sesudah pemberian nasi beras hitam (Oriza Sativa L. Indica) selama satu minggu dengan frekuensi 3 kali sehari dengan porsi 
disesuaikan kebutuhan kalorinya. Penderita diabetes mellitus yang mengalami perubahan kadar glukosa darah normal berjumlah 30 orang, dan yang tidak mengalami perubahan glukosa darah normal namun tetap mengalami penurunan setelah diberikan nasi beras hitam (Oriza Sativa L. Indica) adalah berjumlah 3 orang.

Analisis Inferensial

Pemberian Nasi Beras Merah (Oriza Nivara) terhadap Perubahan Kadar Glukosa Darah

Tabel. 5

Uji Statistk Wilcoxon Signed Ranks Test

Pemberian Nasi Beras Merah (Oriza Nivara)

\begin{tabular}{lccccc}
\hline $\begin{array}{l}\text { Pemberian Nasi Merah } \\
\text { (Oriza Nivara) }\end{array}$ & Median & Maximum & Maximum & $\begin{array}{r}\text { Uji } \\
\text { Statistik }\end{array}$ & P-Value \\
\hline $\begin{array}{l}\text { Pengukuran Kadar } \\
\begin{array}{l}\text { Glukosa Darah Pre- } \\
\text { Post Test (1 Minggu) }\end{array}\end{array}$ & 380.000 & 201 & 580 & 0,00 & 0,000 \\
\hline
\end{tabular}

Berdasarkan tabel 5 menunjukkan bahwa pada pemeriksaan kadar glukosa darah sebelum dan sesudah pemberian nasi beras merah (Oriza Nivara) dalam waktu 1 minggu diperoleh p-value $=0,000$. Hal ini menunjukkan bahwa ada pengaruh pemberian nasi beras merah (oriza nivara) terhadap perubahan glukosa darah pada penderita diabetes mellitus di Kota Kendari.

\section{Pengaruh Pemberian Nasi Beras Hitam (Oriza sativa L. Indica) terhadap Perubahan Kadar Glukosa Darah pada Penderita Diabetes Mellitus di Kota Kendari}

Tabel. 6

Uji Statistk Wilcoxon Signed Ranks Test Pemberian Nasi Beras Merah (Oriza Nivara) Beras Hitam (Oriza Sativa L. Indica) terhadap Perubahan Kadar Glukosa Darah pada Penderita Diabetes Mellitus

\begin{tabular}{lccccc}
\hline $\begin{array}{l}\text { Pemberian Nasi Beras } \\
\text { Hitam (Oriza sativa L. } \\
\text { Indica) }\end{array}$ & Median & Maximum & Maximum & $\begin{array}{c}\text { Uji } \\
\text { Statistik }\end{array}$ & P-Value \\
\hline $\begin{array}{l}\text { Pengukuran Kadar } \\
\text { Glukosa Darah Pre- }\end{array}$ & 350.000 & 220 & 585 & 0,00 & 0,000 \\
\hline \begin{tabular}{l} 
Post Test (1 minggu) \\
\hline
\end{tabular}
\end{tabular}

Setelah dilakukan uji statistik wilcoxon signed ranks test dengan taraf signifikan yang ditetapkan adalah p-value < 0,05 pada pemeriksaan kadar glukosa darah sebelum dan sesudah pemberian nasi beras hitam (Oriza Sativa L. Indica) dalam waktu 1 minggu diperoleh $\mathrm{p}$-value $=0,000$ dari data tersebut $\mathrm{p}$-value $<0,05$. Hal ini menunjukkan bahwa ada pengaruh pemberian nasi beras hitam (Oriza Sativa L. Indica) terhadap perubahan glukosa darah pada penderita diabetes mellitus di Kota Kendari. 


\section{Perbedaan Pemberian Nasi Beras Merah (Oriza Sativa) dengan Nasi Beras Hitam (Oriza Sativa L. Indica) terhadap Perubahan Kadar Glukosa Darah pada Pasien Diabetes Mellitus di Kota Kendari}

Tabel. 7

Uji Statistik pada Pemberian Nasi Beras Merah (Oriza Nivara) dan Nilai Selisih Nasi Beras Hitam

(Oriza Sativa L. Indica) terhadap Perubahan Kadar Glukosa Darah pada Penderita Diabetes Mellitus

\begin{tabular}{lccccc}
\hline Kadar Glukosa Darah & Mean & $\begin{array}{c}\text { Standar } \\
\text { Deviasi }\end{array}$ & Beda Rerata & $\begin{array}{c}\text { Uji } \\
\text { Statistik }\end{array}$ & P-Value \\
\hline $\begin{array}{l}\text { Nilai Selisih Pemberian } \\
\text { Nasi Beras Merah }\end{array}$ & 164,24 & 108,16 & $\begin{array}{c}-31,30(-79,40 \\
-16,80)\end{array}$ & 0,19 & 0,000 \\
\hline $\begin{array}{l}\text { Nilai Selisih Pemberian } \\
\text { Nasi Beras Merah }\end{array}$ & 195,55 & 86,21 & & & \\
\hline
\end{tabular}

Setelah dilakukan uji statistik independent sample t-test dengan taraf signifikan yang ditetapkan adalah p-value < 0,05 pada perbandingam antara nilai selisih kelompok pemberian nasi beras merah (Oriza Nivara) dan nilai selisih kelompok pemberian nasi beras hitam (Oriza Sativa L. Indica) terhadap perubahan kadar glukosa darah diperoleh $\mathrm{P}$ Value $=0,19$ dari data tersebut p-value $<0,05$. Hal ini menunjukkan bahwa tidak ada perbedaan bermakna antara pemberian nasi beras merah (Oriza Nivara) dan nasi beras hitam (Oriza Sativa L. Indica) terhadap perubahan glukosa darah pada penderita diabetes mellitus di Kota Kendari.

\section{PEMBAHASAN}

\section{Pengaruh Pemberian Nasi Beras Merah (Oriza Nivara) terhadap Perubahan Kadar Glukosa Darah pada Penderita Diabetes Mellitus}

Pengukuran kadar glukosa darah pada penderita diabetes mellitus, sebelum dan sesudah pemberian intervensi nasi beras merah (oriza nivara) dengan rentang waktu selama 1 minggu frekuensi 3 kali sehari dengan porsi disesuaikan kebutuhan kalorinya. Dengan demikian bahwa penderita yang mengalami glukosa darah dalam rentang normal $\leq 200$ $\mathrm{mg} / \mathrm{dl}$ sebanyak 19 orang penderita diabetes mellitus, sedangkan penderita yang tidak mengalami perubahan kadar glukosa darah masih diatas > $200 \mathrm{mg} / \mathrm{dl}$ sebanyak 14 orang penderita. Hasil uji normalitas data diperoleh data tidak berdistribusi normal sehingga dilanjutkan dengan uji statistik non parametrik wilcoxon signed ranks test dengan taraf signifikan yang ditetapkan adalah p-value $<0,05$ pada pemeriksaan kadar glukosa darah sebelum dan sesudah pemberian nasi beras merah (Oriza Nivara) dalam waktu 1 minggu diperoleh $\mathrm{p}$-value $=0,000$ dari data tersebut $\mathrm{p}$-value $<0,05$. Hal ini menunjukkan bahwa ada pengaruh pemberian nasi beras merah (Oriza Nivara) terhadap perubahan glukosa darah pada penderita diabetes mellitus di Kota Kendari.

Hasil penelitian tersebut sejalan dengan penelitian Kuszairi (2017) dari 76 pasien diabetes mellitus sebelum dan sesudah pemberian intervensi beras merah selama 1 minggu diperoleh hasil beras merah efektif terhadap penurunan kadar glukosa darah pada pasien diabetes mellitus. Pada penelitian Pradini et al., (2018) dari total sampel penelitian berjumlah 36 sampel yang terdiri dari kelompok perlakuan diberikan pemberian nasi merah 
selama 6 hari pada waktu sarapan dan makan malam, sedangkan kelompok kontrol tidak mendapat intervensi apapun. Hasil penelitian rata-rata kadar kolesterol awal dan akhir kelompok perlakuan 235,69 mg/dL dan 198,56 mg/dL, sedangkan kadar kolesterol awal dan akhir kelompok kontrol 235,72 mg/dL dan 256,50 mg/dL. Pada penelitian ini pemberian nasi merah efektif untuk menurunkan kadar kolesterol total pasien Diabetes mellitus tipe 2 .

Proses perubahan glukosa darah dengan pemberian nasi beras merah (Oriza Nivara) dikarenakan kandungan serat yang tinggi pada beras merah. Manfaat serat dalam kandungan beras merah dapat meningkatkan viskositas lumen dalam usus sehingga dapat menurunkan efisiensi penyerapan karbohidrat dan respon insulin. Dengan menurunnya respon insulin maka kerja dari pankreas akan semakin ringan dalam memproduksi insulin. Beras merah (Oriza Nivara) juga dapat menurunkan kadar lipid dalam serum sehingga dapat menekan kadar glukosa dalam darah. Selain itu pula, beras merah memiliki kandungan mineral selenium dan pigmen antosianin (merah) yang berfungsi sebagai antioksidan dan menjadi penghambat dari berbagai macam penyakit degeneratif termasuk diabetes mellitus (Kuszairi, 2017; Setyawati, 2020).

Adapun penderita diabetes mellitus setelah diberikan nasi beras merah (Oriza Nivara) namun tidak terjadi perubahan dalam rentang normal diakibatkan oleh masih terdapatnya penderita mengkonsumsi makanan yang dapat memicu peningkatan glukosa darah, meminum kopi, merokok yang dapat menyebabkan peningkatan glukosa darah pada penderita diabetes mellitus.

Faktor eksternal yang menyebabkan tidak terjadinya perubahan kadar glukosa darah setelah diberikan intervensi nasi beras merah (Oriza Nivara) yaitu penderita memiliki berbagai karakteristik usia dan jenis kelamin. Seseorang yang berusia 35 tahun keatas akan lebih memiliki resiko mengalami hiperglikemia postprandial dibandingkan seseorang kurang dari usia 35 tahun.

\section{Pengaruh Pemberian Nasi Beras Hitam (Oriza Sativa L. Indica) terhadap Perubahan Kadar Glukosa Darah pada Penderita Diabetes Mellitus}

Pengukuran kadar glukosa darah pada penderita diabetes mellitus, sebelum dan sesudah pemberian intervensi nasi beras hitam (Oriza Sativa L. indica) dengan rentang waktu selama 1 minggu frekuensi 3 kali sehari dengan porsi disesuaikan kebutuhan kalorinya. Dengan demikian bahwa penderita yang mengalami perubahan glukosa darah dalam rentang normal $\leq 200 \mathrm{mg} / \mathrm{dl}$ sebanyak 30 orang penderita diabetes mellitus, sedangkan penderita yang tidak mengalami perubahan kadar glukosa darah masih diatas > $200 \mathrm{mg} / \mathrm{dl}$ sebanyak 3 orang penderita. Hasil uji normalitas data diperoleh data tidak berdistribusi normal sehingga dilanjutkan dengan uji statistik non parametrik wilcoxon signed ranks test dengan taraf signifikan yang ditetapkan adalah $\mathrm{P}$-value $<0,05$ pada pemeriksaan kadar glukosa darah sebelum dan sesudah pemberian nasi beras hitam (Oriza Sativa L. Indica) dalam waktu 1 minggu diperoleh p-value $=0,000$ dari data tersebut $\mathrm{P}$ value $<0,05$. Hal ini menunjukkan bahwa ada pengaruh pemberian nasi beras hitam (Oriza Sativa L. Indica) terhadap perubahan glukosa darah pada penderita diabetes mellitus di Kota Kendari.

Penelitian ini sejalan dengan penelitian yang dilakukan oleh Anggraini et al., (2019) beras hitam merupakan sebagai agen terapi yang dapat menurunkan kadar glukosa darah 
pada pasien penderita diabetes mellitus di Desa Sobayan Kecamatan Pedan Kabupaten Klaten. Kandungan beras hitam berperan dalam penurunan kadar glukosa darah yaitu antosianin yang di dalamnya terdapat senyawa aktif sianidin-3-glukosida berfungsi memperbaiki keadaan hiperglikemia dan memiliki potensi untuk memperbaiki resistensi insulin. Kandungan lain dari antosianin yaitu pelagornidin-3-galaktosida yang memiliki kemampuan untuk meningkatkan sekresi insulin, selain itu juga berperan sebagai antioksidan yang bekerja dengan cara melindungi sel $\beta$ pankreas terhadap peningkatan Reactive Oxygen Species (ROS) pada kondisi hiperglikemia serta sekaligus mengurangi stres oksidatif pada penderita diabetes mellitus, sehingga penggunaaan aktioksidan mampu mencegah adanya komplilkasi diabetes (Anggraini et al., 2019).

\section{Perbandingan Pemberian Nasi Beras Merah (Oriza Nivara) dan Nasi Beras Hitam (Oriza Sativa L. Indica) terhadap Perubahan Kadar Glukosa Darah pada Penderita Diabetes Mellitus}

Perbandingan permberian nasi beras merah (Oriza Nivara) dan nasi beras hitam (Oriza Sativa L. Indica) terhadap perubahan kadar glukosa darah pada penderita diabetes mellitus di Kota Kendari, dilihat dari nilai selisih antar kelompok pemberian intervensi nasi beras merah (Oriza Nivara) dan nasi beras hitam (Oriza Sativa L. Indica). Hasil uji normalitas data menggunakan uji statistik kolmogorov-smirnov dari jumlah sampel kedua pemberian intervensi adalah 66 orang penderita diperoleh data berdistribusi normal. Oleh karena itu, uji normalitas yang digunakan adalah uji statistik parametrik independent sample t-test dengan taraf signifikan yang ditetapkan adalah p-value $<0,05$ pada perbandingan antara nilai selisih kelompok pemberian nasi beras Merah (Oriza Nivara) dan nilai selisih kelompok pemberian nasi beras hitam (Oriza Sativa L. Indica) terhadap perubahan kadar glukosa darah diperoleh p-value $=0,19$ dari data tersebut $\mathrm{p}$-value $<0,05$. Hal ini menunjukkan bahwa tidak ada perbedaan bermakna antara pemberian nasi beras merah (Oriza Nivara) dan nasi beras hitam (Oriza Sativa L. Indica) terhadap perubahan glukosa darah pada penderita diabetes mellitus di Kota Kendari.

Pada penelitian Hernawan \& Meylani (2016) menunjukkan bahwa kandungan serat beras hitam (Oriza Sativa L. Indica) lebih tinggi dibandingkan dengan beras merah (Oriza Nivara). Berdasarkan hasil penelitian bahwa beras hitam (Oriza Sativa L. Indica) memiliki indeks glilkemik lebih rendah serta lebih tinggi kandungan serat antosianinnya dibandingkan dengan beras merah (Oriza Nivara) yang berperan dalam meningkatkan sensitivitas insulin sehingga glukosa dalam darah mampu diserap masuk ke dalam sel. Kandungan antosianin yang tinggi diketahui mencegah kerusakan sel - sel pankreas serta menekan apoptosis sel pankreas tanpa mengubah proliferasi dari sel tersebut (Daeli \& Ardiaria, 2018).

Pada penelitian ini hasil pemeriksaan sebelum dan sesudah kadar glukosa darah pada penderita diabetes mellitus diperoleh ada perbedaan nilai selisih kelompok antara pemberian nasi beras merah (Oriza Nivara) dan nasi beras hitam (Oriza Sativa L. Indica), Namun pada uji statistik tidak menunjukkan perbedaan bermakna. Menurut pengamatan peneliti, tidak terjadinya perbedaan bermakna diakibatkan karena nasi beras merah (Oriza Nivara) dan nasi beras hitam (Oriza Sativa L. Indica) sama - sama memiliki kandungan serat yang berfungsi menurunkan glukosa dalam darah, pada penderita diabetes mellitus. 


\section{SIMPULAN}

Ada pengaruh pemberian nasi beras merah (Oriza Nivara) dan nasi beras hitam (Oriza Sativa L. Indica) terhadap perubahan glukosa darah pada penderita diabetes mellitus di Kota Kendari, pada perbandingan antara nasi beras merah (Oriza Nivara) dan nasi beras hitam (Oriza Sativa L. Indica) diperoleh tidak ada perbedaan bermakna antara kedua pemberian intervensi.

\section{SARAN}

Bagi penderita diabetes mellitus agar dapat mengkonsumsi nasi beras merah (Oriza Nivara) dan nasi beras hitam (Oriza Sativa L. Indica) sebagai parameter perubahan pada glukosa dalam darah, sedangkan pada penelitian selanjutnya pemberian intervensi nasi beras merah (Oriza Nivara) dan nasi beras hitam (Oriza Sativa L. Indica) terhadap penurunan kolesterol pada penderita diabetes mellitus.

\section{DAFTAR PUSTAKA}

Anggraini, D. I., Semartini, A., \& Cahyani, V. A. (2019). Beras Ketan Hitam sebagai Agen Terapi pada Pasien Penderita Diabetes Mellitus di Desa Sobayan Kecamatan Pedan Kabupaten Klaten. Abdimas Unwahas, 4(1), 10-13. https://doi.org/10.31942/abd.v4i1.2689

Daeli, E., \& Ardiaria, M. (2018). Pengaruh Pemberian Nasi Beras Merah (Oryza Nivara) dan Nasi Beras Hitam (Oryza Sativa L.Indica) terhadap Perubahan Kadar Gula Darah dan Trigliserida Tikus Wistar (Rattus Norvegicus) Diabetes Mellitus Tipe 2. JNH (Journal Of Nutrition and Health), 6(2), 42. https://doi.org/10.14710/jnh.6.2.2018.4256

Depkes, R. I. (2018). Data dan Informasi Profil Kesehatan Indonesia

Edy, E., \& Adinugraha, T. S. (2017). Hubungan Asupan Makronutrien dengan Nilai Kadar Glukosa Darah pada Pasien Diabetes Mellitus Tipe 2 di Rumah Sakit Umum Panembahan Senopati Bantul Yogyakarta [Sekolah Tinggi Ilmu Kesehatan Jenderal Achmad Yani]. http://repository.unjaya.ac.id/2272/2/ERNIYANI EDY_2213155_pisah.pdf

Firdausya, H., \& Amalia, R. (2020). Review Jurnal: Aktivitas dan Efektivitas Antidiabetes pada Beberapa Tanaman Herbal. Farmaka, 18(1), 162-170. http://jurnal.unpad.ac.id/farmaka/article/view/22467

Hernawan, E., \& Meylani, V. (2016). Analisis Karakteristik Fisikokimia Beras Putih, Beras Merah, dan Beras Hitam (Oryza Sativa L., Oryza Nivara dan Oryza Sativa L. Indica). Jurnal Kesehatan Bakti Tunas Husada: Jurnal Ilmu-Ilmu Keperawatan, Analis Kesehatan dan Farmasi, 15(1), 79. https://doi.org/10.36465/jkbth.v15i1.154

Kemenkes RI. (2019). Profil Kesehatan Indonesia 2018 Kemenkes RI. (2019)

Kuszairi, K. (2017). Efektifitas Pemberian Diet Beras Merah dalam Menurunkan Kadar Gula Darah pada Penderita Diabetes Mellitus di Puskesmas Pademawu Pamekasan. Journal of Islamic Medicine, 1(2), 97-107. https://doi.org/10.18860/jim.v1i2.4458

Pradini, W. U., Marchianti, A. C. N., \& Riyanti, R. (2018). Efektivitas Nasi Merah untuk Menurunkan Kadar Kolesterol Total Pasien DM Tipe 2. Journal of Agromedicine and Medical Sciences, 3(1), 7-12. https://repository.unej.ac.id/handle/123456789/84320 
Riskesdas. (2018). Hasil Utama Riset Kesehatan Dasar. Kementrian Kesehatan Republik Indonesia, 1-100. https://doi.org/https://doi.org/10.1088/1751-8113/44/8/085201

Sartika, A., Betrianita, B., Andri, J., Padila, P., \& Nugrah, A. V. (2020). Senam Lansia Menurunkan Tekanan Darah pada Lansia. Journal of Telenursing, 2(1), 11-20. https://doi.org/https://doi.org/10.31539/joting.v2i1.1126

Setyawati, A. D., Ngo, T. H. L., Padila, P., \& Andri, J. (2020). Obesity and Heredity for Diabetes Mellitus among Elderly. JOSING: Journal of Nursing and Health, 1(1), 2631. https://doi.org/https://doi.org/https://doi.org/10.31539/josing.v1i1.1149

Susanti, S., \& Bistara, D. N. (2018). Hubungan Pola Makan dengan Kadar Gula Darah pada Penderita Diabetes Mellitus. Jurnal Kesehatan Vokasional, 3(1), 29. https://doi.org/10.22146/jkesvo.34080 